\title{
ACCOUNTABILITY OF DISCRETION ACT BY GOVERNMENT OFFICIALS IN THE PERSPECTIVE OF STATE LAW OF WELFARE
}

\author{
Asmak Ul Hosnah $^{\left.a^{*}\right)}$, Edi Rohaedi ${ }^{a)}$ \\ a) Pakuan University, Bogor, Indonesia \\ ${ }^{*}$ Corresponding Author: asmak.hosnah@unpak.ac.id
}

Article history: received 29 January 2020; revised 19 February 2020; accepted 16 February 2020

\begin{abstract}
Accountability of government officials' actions is strongly related to the exercise of government authority. In carrying out duties to realize the general welfare, the authority used by organs or government officials is based on the provisions of the laws and regulations (the principle of legality). However, it is not uncommon for the task to be carried out based on discretionary authority. The freedom of government officials to make decisions based on discretionary authority has a great potential to be abused which results in consequences from both point of view of administrative law as well as of criminal law. In the practice, there is discrepancy among law enforcers on the understanding of the principles related to the accountability of discretionary authority held by government officials.
\end{abstract}

Keywords: accountability; discretion: government officials

\section{INTRODUCTION}

Article 1 Paragraph (3) of the 1945 Constitution of the Republic of Indonesia (The Third Amendment) confirms "The State of Indonesia is a state of law." In relation to the statement, the meaning of state of law is inseparable from the pillar, which is law sovereignty. In addition, the founding fathers of the state, in forming the Indonesia state government, have determined other pillar, the sovereignty of the people. It embodies the integral unification between the understanding of law sovereignty and the sovereignty of the people. Then it is contradicted and strictly separated between the state of law on the one hand and the state of power on the other which can be incarnated as in the form of dictatorship or other similar forms, which are undesirable to be carried out in this motherland [1].

The existence of a state referred to as a state of law is reflected in several things, which are usually stated as the features of the state of law (rechtsstaat). These features are generally can be found in the 1945 Constitution [2]. These features are: a. Guarantee on human rights (and citizens); $b$. Division of power within the state (scheiding van macht); $\mathrm{c}$. The government in carrying out its duties and obligations must be based on the law, both written and unwritten; and $\mathrm{d}$. The existence of an independent judicial power.

The state of Indonesia is a welfare state if based on the objectives of the country as stated in Paragraph IV of the Opening of the 1945 Constitution of the Republic of Indonesia [3]. Countries that adhere to the principles of the Welfare State other than Indonesia are the Netherlands and France [4].

People's welfare as the ultimate goal of the welfare state covers a very broad scope. The task of government in the welfare state is called Lemaire "bestuurszorg" [5]. This term implies as the task of carrying out public welfare which makes the government must be active in the association of people (citizens). In other words, bestuurszorg becomes a mark of welfare state [5]. The great authority of government opens opportunities for the abuse of authority (power) [6]. In order to prevent this possibility, the welfare state enforces limitations on power. According to Gautama [6], the principle of limiting power is one of the characteristics of the welfare state. The restriction of power is guided by the well-known legal principle of state administration, the principle of legality [7]. In accordance with the principle of legality, Hadjon [8] states that every government action must be carried out based on legal authority and based on proper procedures and substance.

The function of the legality principle can be viewed from the perspective of the authorities and the people (citizens). From the point of view of the authorities, the principle of legality functions as the restriction of power and the legal basis of the state administrators. State policy is set in the form of legal products by legislators as institutions that are authorized to impose restrictions [9]. Meanwhile, from the people's point of view, the principle of legality serves as a means of legal protection for the rights of citizens with the aim of providing legal certainty.

\section{RESEARCH METHOD}

The research method used is a normative legal research method which is conducted as an effort to obtain the data needed in connection with the problem. The data used are secondary data consisting of primary legal materials, secondary legal materials, and tertiary legal materials. In addition, primary data is also used as supporting secondary data. Data analysis was performed using qualitative juridical analysis methods.

\section{RESULT AND DISCUSSION}

\section{A. The Concept of Discretionary Authority in Administrative Law}

As the consequence of the legality principle, the establishment of written legislation is an absolute necessity. 
However, Manan [10] states that written law has weaknesses or innate defects (natural defects) and artificial defects (artificial defects). He explains that legislation as a form of written law has a limited reach - just an opname moment from the political, economic, social, cultural and security elements that are most influential at the time of formation [10]. Ridwan added that Legislation is easy to be "out of date" when compared to changes in society that are getting faster and faster [11]. As a result, written legislation can be a source of failure in organizing public welfare. In accordance with the principle of legality, every government action carried out must be based on legitimate authority, established procedures and proper substance [8].

The weakness of the written law makes the government faces difficulties when dealing with concrete problems that have not been regulated by the law. This result to the birth of new administrative legal principles in accordance with the demands of the needs and development of society, the socalled discretionary principle or freies ermessen, pouvoir discretionnaire [12] [13]. The principle of discretion gives unrestrained authority to government officials to take action on their own initiative in certain circumstances when concrete issues that have not been regulated in law arise [13]. The principle of discretion becomes the pair of legality principle as the pillar of the welfare state law.

The principle of discretion serves, among other things, to fill the vacuum of law, to facilitate the administration of government, provide legal certainty or to overcome stagnation in the order of public benefit and interest. The principle of discretion provides flexibility for the government to be able to carry out the task of organizing public welfare without being bound to the law [14]. The discretionary authority of the government is related to the function of public service. Scheltema proposed that the government and government officials carry out the mandate as a public servant to realize the welfare of the community in accordance with the purpose of a state [15]. Public service is a characteristic of welfare state as a manifestation of state social responsibility.

In the frame of Indonesia's welfare state, the regulation of the discretion principle is stipulated in Article 6 paragraph (1) of Law Number 30 of 2014 concerning Government Administration which states "Government Officials have the right to use the authority in making decisions and / or actions" [16]. One of the authorities in question is the right to use discretionary authority as regulated in Article 6 paragraph (2) Letter e of Law Number 30 of 2014 as follows "Rights as referred to in paragraph (1) include using discretion in accordance with their objectives" [16]. In other words, discretionary authority is limited by the law. Article 1 number (9) of Law Number 30 of 2014 states "Discretion is a decision and/or action determined and/or carried out by a government official to address concrete problems encountered in the administration of government in terms of laws and regulations that provide choices, are not regulated, incomplete or unclear, and/or government stagnation" [16]

Restrictions on discretion include restrictions in terms of the subject of public law (position) and in terms of aims and objectives. Restrictions on legal subjects are regulated by
Article 22 paragraph (1) of Law Number 30 of 2014 as follows "Discretion can only be carried out by authorized Government Officials" [16]. Public legal subjects that are allowed to use discretionary authority are authorized positions. Limitation of discretionary authority is also regulated from the point of intention and purpose as stipulated in Article 22 paragraph (2) of Law Number 30 of 2014 which reads "Every use of Government Official Discretion aims to: (a). Streamlining the administration of government; (b). Fill in the legal vacuum; (c). Provide legal certainty; and (d) overcome the stagnation of government in certain circumstances for the benefit and public interest" [16].

The issue of using discretionary authority arises when discretionary authority is applied to concrete events, because the provisions of Article 22 paragraph (2) of Law Number 30 of 2014 still required to be interpreted. Terms in Article 22 paragraph (1) of Law Number 30 of 2014 still covers a very broad and abstract scope. Therefore, according to the researchers, these terms cannot necessarily be applied to concrete cases without interpretation and study. The principles in Article 22 paragraph (1) of Law Number 30 of 2014 needs to be assessed and determined by standard so that the application of discretion to a concrete event can be challenged.

If the principle of using discretionary authority is not standardized, legal problems will arise since the use of discretionary authority can be interpreted as an abuse of authority that impacts on criminal law. These restrictions can be seen as well as the principle of the use of discretionary authority permitted by law and not categorized as unlawful acts. Before Law Number 30 of 2014 stipulated, the discussion of authority discretion of government officials does not yet have a positive legal basis in judicial practice. Government officials can interpret freely about the conditions that require the use of discretionary authority according to the consideration and understanding of the relevant government official. Prior to Law Number 30 of 2014, the principle of using discretionary powers such as to (1) reinforce the administration of government, (2) fill the legal vacuum, (3) provide legal certainty and (4) overcome government stagnation in certain circumstances for public benefit and benefit only known in the realm of doctrine.

Unclear discretionary authority makes government officials, law enforcer and judicial institution differ in their views on the use of discretion in various cases. The situation happened because of several things. First, the principle of conditions, circumstances and purpose of using discretionary authority is not regulated in the law so that everyone has a different view. Secondly, the absence of the principle in using discretionary authority makes law enforcers have different views in assessing and, at the same time, determining actions based on discretionary authority in order to decide which should be deemed to fulfill elements of a criminal offense or not fulfill an element of a criminal offense. Policies determined based on discretionary authority may come into contact with criminal offenses in the form of acts that violate the law, abuse the authority and cause losses to the state. If the above elements are contained in the policies of government officials based on discretion, the act is very likely to be 
considered a criminal act that needs to be held accountable in terms of criminal law.

In legal science, there are legal principles that teach every authority must be accompanied by accountability. All actions of government officials based on authority must be accompanied by accountability. The principle of accountability can be applied to the actions of government officials based on legality and discretionary authority. The discussion of liability for discretion can be discussed from the perspective of both state administrative law and criminal law. Government action based on the principle of legality means that the action is based on bounded authority (gebonded bevoegheid) because there are positive legal norms governing the action. Relatively, the actions of the government apparatus based on the principle of legality are more easily tested for legal validity because there are already positive legal norms governing these actions. The act of government official based on discretion means that the action is based on unrestricted authority (free authority) [11]. Discretion is called an action based on free authority because the authority to carry out the action is not regulated in positive legal norms.

\section{B. Accountability of Discretion Acts by Government Official in the Practice of Governance}

As have been stated, the actions of government officials based on discretionary authority are not absolutel y free acts. However, actions are limited by the provisions of various aspects. Actions of government officials based on discretionary authority can be seen as a right and valid actions if they fulfill the following criteria: (1) in accordance with the purpose of using discretionary authority; (2) according to the scope of consideration of government officials in carrying out discretionary acts; (3) meet the requirements; and (4) based on the procedures set out in the legislation (Law Number 30 of 2014). Therefore, the actions of government officials based on discretionary authority that meet the criteria as stated above are government actions that do not cause problems from a legal standpoint hence that they cannot be questioned from the perspective of state administrative law.

In the practice of state administration and governance, the actions of government officials based on discretionary powers that deviate or violate the provisions of the legislation (Law Number 30 of 2014) are common or often occur. The actions of government officials often occur in the practice of government administration because the discretionary authority belongs to government officials based on "space of judgments to freely evaluate" [17]. This characteristic makes the discretionary authority have great potential or is very open to be abused by the government official, given the subjective consideration in assessing a concrete situation or event opens the opportunity to take various forms of discretion which deviate from or violate the laws and regulations.

In the context of governance practice in the framework of the welfare state, the actions of government officials based on discretionary authority that violate or violate the laws and regulations as stated above must be avoided or prevented because they will cause harm to the people. Prohibition of abuse of authority by government officials regulated in Article
17 paragraph (1) of Law Number 30 of 2014 that reads "Government agencies and/or officials are prohibited from abusing authority" [16]. Prohibition of abuse of authority is referred to in Article 17 paragraph (1) of Law Number 30 of 2014 above is a prohibition on abuse of authority that is general in nature. The provisions governing the prohibition of abuse of authority by government officials that are general in nature cover all types of authority. Three types of actions or actions of government officials based on discretionary authority are categorized as deviant regulated in Article 17 paragraph (2) of Law Number 30 of 2014 are as follows: "(a) prohibition of exceeding authority, (b) prohibition of mixing authority and (c) prohibition of arbitrary action" [16].

Each form of abuse of authority by a government official as mentioned above has different meanings, nature and characteristics. Therefore, according to the author, the three forms of acts of abuse of authority referred to above also contain or cause legal problems, legal risks, and various severity of penalties according to the form, nature and characteristics of the authority abuse.

The legislation which is Law Number 30 of 2014 does not formulate an understanding of the legal concept of the actions of government officials which falls into the category of "actions beyond authority". However, Article 18 paragraph (1) of Law Number 30 Year 2014 categorizes actions beyond authority, which are "(1) beyond the term of office or the deadline for the enactment of authority; (2) beyond the territorial limits of the enactment of authority, and/or (3) contrary to the provisions of the legislation" [16].

The statutory regulation also does not stipulate the definition or definition of "the act of confusing authority". However, it submits the formulation of the definition of "action beyond authority" to state expert of administrative law and expert of the studies of state administrative law. However, according to the provisions of Article 18 paragraph (1) of Law Number 30 of 2014 stated above, the actions of government officials included in the category of "actions beyond authority" are actions that are outside the scope of the field or material of the authority granted, and/or contrary to the purpose of the authority granted. Essentially the author can state that the two forms of "conflating authority" referred to above are the actions of government officials that are contrary to "the purpose of the authority granted and take action outside the limits of authority" specified in the legislation. According to the experts, "the act of mixing up authority" is referred to by another term as an act or "act of abusing authority (de tournement de pouvoir)."

State administrative law sanctions that can be imposed on actions by government officials based on discretionary authority that fall into the category of "confusing authority" are actions that can be "canceled" as regulated in Article 31 paragraph (2) of Law Number 30 of 2014 which regulates that "the legal consequences of the use of discretionary authority as referred to in paragraph (1) may be canceled" [16]. The action referred to in Article 31 paragraph (1) of Law Number 30 of 2014 is an "act of confusing authority". Whereas the form of acts of abuse of authority in the form of "arbitrary actions" are the actions actions that are without a basis of 
authority and or in contrary to court decisions that have permanent legal force. Therefore, if the forms of "arbitrary" actions stated above are combined in one sense, the author can establish the understanding that arbitrary acts are actions of government officials carried out without basis of authority or contrary to a court decision which has the power permanent law. It is regulated in Article 18 paragraph (3) of Law Number 30 of 2014 mentions the category of arbitrary actions which reads "institution and/or government officials actions are categorized arbitrary as referred to in Article 17 paragraph (2) letter $\mathrm{c}$ if the decision and/or action taken are (1) without basis of authority and/or (2) in contrary to a court decision having permanent legal force" [16].

In this sense, it can be said that, essentially, the two forms of "arbitrary" are the actions of government officials who are without basis of authority or are contrary to court decisions that have permanent legal force. The actions of government officials in the form of "arbitrary acts" as mentioned above are formulated in different legal terms according to the views of legal experts and Legal Knowledge. According to the expert, "arbitrary acts" are referred to by other terms as actions or "abuse of power" or "willekeur" or "abus de droit".

State administrative law sanctions that can be imposed on actions by government officials based on discretionary authority which are categorized as "arbitrary" are those acts of discretion "becoming invalid". These sanctions are regulated in Article 32 paragraph (2) of Law Number 30 of 2014 which states that "The legal consequences of the use of discretionary authority as referred to in paragraph (1) become invalid" [16]. The action referred to in Article 32 paragraph (1) of Law Number 30 of 2014 is an arbitrary act.

According to the authors, indicators of accountability for the actions of government officials based on discretionary authority as stipulated in Law Number 30 of 2014 is a form of limitation on the dicrestionary authority of government officials that is too rigid or strict. Indicators that are too strict can make the purpose and objectives of Law Number 30 of 2014 in giving discretionary authority to government officials to be used at any time, if a sudden and unregulated concrete problem arises in the legislation, becomes unproductive. In addition, it leads to discretionary authority of government officials become as if the authority based on the principle of legality that is regulated it is strictly and expressly in written statutory regulations.

\section{CONLCUSION}

In the perspective of the welfare state principle, the indicators of government officials' actions based on discretionary authority should be viewed from the point of view of state administrative law so that government actions based on such discretion are not categorized as abuse of authority (de tournrments de pouvoir) or arbitrary actions (willekeur or abus de dorit or abuse of power). Whilein the context of the practice of governance within the framework of the welfare state, the forms of actions of government officials based on discretionary authority that are deviant or violate the laws and regulations must be avoided or prevented because they will cause harm to the people.

\section{REFERENCES}

[1] S. Basah, Perlindungan Hukum Terhadap Sikap Tindak Administrasi Negara [Legal Protection Against Attitudes to State Administration]. Bandung: Alumni, 1992.

[2] S. M. Soemantri, Kemandirian Kekuasaan Kehakiman Sebagai Prasyarat Negara Hukum Indonesia [Independence of Judicial Power as a Prerequisite for the Indonesian Law State], Makalah, Seminar "50 Tahun Kemandirian Kekuasaan Kehakiman di Indonesia". Jogjakarta: FH-UGM, 1995.

[3] P. Wahyono, Negara Hukum Indonesia [Indonesian State of Law]. Jakarta: Radja Grafindo Persada, 1982.

[4] M. T. Azhary. Negara Hukum Indonesia [Indonesian State of Law]. Jakarta: UI Press, 1995.

[5] E. Utrecht, Pengantar Hukum Administrasi Negara Indonesia [Introduction to Indonesian State Administrative Law]. Jakarta: Ichtiar Baru, 1962, p. 23.

[6] S. Gautama, Pengertian Tentang Negara Hukum [Understanding on Law State]. Bandung, Alumni, 1983. [7] M. Bachsan. Pokok-pokok Hukum Administrasi Negara [Principles of State Administrative Law]. Bandung: Alumni, 1979.

[8] P. M. Hadjon et.al., Hukum Administrasi Dan Tindak Pidana Korupsi [Administrative Law and Corruption Crime]. Yogyakarta: GMU Press, 2012.

[9] P. Wahyono, Indonesia, Negara Berdasarkan Atas Hukum [Indonesia, A State based on Law]. Jakarta: Ghalia Indonesia, 1986

[10] B. Manan, "Peranan Hukum Administrasi Negara Dalam Pembentukan Peraturan Perundang-undangan', [The Legal Role of State Administration Law in Forming Regulations and Regulations], presented at Penataran Nasional Hukum Acara dan Hukum Administrasi Negara. Ujung Pandang: Fakultas Hukum UNHAS, 1996.

[11] H. R. Ridwan, Diskresi \& Tanggung Jawab Pemerintah [Government Discretion \& Responsibility]. Yogyakarta: FH UII Press, 2014.

[12] D. H. Koesomehatmadja, Pokok-pokok Hukum Tata Usaha Negara, [Principles of State Administrative Law]. Bandung: Alumni, 1983.

[13] H. R. Ridwan, Hukum Administrasi Negara [State Administrative Law]. Jakarta: Rajawali, 2008.

[14] H. P. Sibuea, Asas Negara Hukum, Peraturan Kebijakan \& Asas-Asas Umum Pemerintahan yang Baik [Principle of LawSate, Policies Regulation \& General Principles of Good Governance]. Jakarta: Erlangga, 2011.

[15] B. A. Sidharta, "Kajian Kefilsafatan tentang Negara Hukum [Philosophical Study of the Rule of Law]." Jurnal Hukum Jentera, Pusat Studi Hukum dan Kebijakan (PSHK), Jakarta, Tahun II Edisi 3, 2004. 
[16] Kementerian Sekretariat Negara [Kemensetneg], Undang-Undang Republik Indonesia Nomor 30 Tahun 2014 tentang Administrasi Pemerintahan [Law of the Republic of Indonesia of 2014 on government Administration]. Jakarta: Kementerian Sekretariat Negara Republik Indonesia, 2014.

[17] Y. M. I. Patrio, Diskresi Pejabat Publik dan Tindak Pidana Korupsi [Discretion of Public Officials and Corruption Crimes]. Bandung: Keni Media, 2012. 